\title{
Estimation of Critical Limits of Zinc in Soil and Plant for Predicting Response of Maize (Zea mays L.) to Zinc and Nutrient Uptake in Acid Soils, Manipur
}

\author{
Pawan Kumar, Herojit Singh Athokpam*, R. K. Kumarjit Singh, \\ Konthoujam Nandini Devi and Naorem Okendro Singh
}

\begin{abstract}
Department of Soil Sc. \& Agricultural Chemistry, College of Agriculture, Central Agricultural University, Imphal, India
\end{abstract}

*Corresponding author

\section{A B S T R A C T}

\begin{tabular}{l} 
K e y w o r d s \\
$\begin{array}{l}\text { Acid soil, Clay, Dry } \\
\text { matter, Nutrients } \\
\text { uptake, Critical } \\
\text { limit, Bray's per } \\
\text { cent yield }\end{array}$ \\
\hline Article Info \\
$\begin{array}{l}\text { Accepted: } \\
\text { 17 September } 2020 \\
\text { Available Online: } \\
\text { 10 October } 2020\end{array}$ \\
\hline
\end{tabular}

Keywords

Acid soil, Clay, Dry matter, Nutrients uptake, Critical limit, Bray's per ent yield

\section{Introduction}

Zinc $(\mathrm{Zn})$ is an indispensable element for plants, animals and humans for various reproductive and physiological processes. Zinc deficiency is more pronounced among the micro-nutrients in India. In the world, half of the cultivated soils are deficient in zinc. In India, the zinc deficiency was the first time was observed on field-scale was in rice crop in tarai soils by Nene in 1966. The zinc
A pot experiment was conducted in 2018 to assess the effects of zinc fertilization on dry matter yield and nutrients uptake of hybrid maize. The treatments consisted of three doses: 0.0, 2.5 and $5.0 \mathrm{~kg} \mathrm{Zn} \mathrm{ha}{ }^{-1}$ as $\mathrm{ZnSO}_{4} \cdot 7 \mathrm{H}_{2} \mathrm{O}$ and hybrid maize variety PAC-740 was as test crop arranged in a completely randomized block design (RCBD) with three replications. The soils were acidic in nature, EC were low, organic carbon in the soils were fairly high (mean $17.71 \mathrm{~g} \mathrm{~kg}^{-1}$ ) and the mean CEC of the soils was $16.36\left[\mathrm{cmol}\left(\mathrm{P}^{+}\right) \mathrm{kg}^{-1}\right]$. All the collected soil samples were clay in textural class. The results showed the addition of $\mathrm{Zn}$ substantial differences in dry matter yield and nutrients uptake of hybrid maize. Positive and significant correlations were obtained between DTPA-Zn and Bray's per cent yield $\left(\mathrm{r}=0.444^{*}\right)$, dry matter yield in control $\left(\mathrm{r}=0.916^{* *}\right)$, $\mathrm{Zn}$ concentration in control $\left(\mathrm{r}=0.966^{* *}\right), \mathrm{Zn}$ uptake in control $\left(\mathrm{r}=0.959^{* *}\right)$ and Bray's per cent uptake $(\mathrm{r}=0.492 *)$. The critical limits of $\mathrm{Zn}$ in soils and 45 days old maize plant was $0.88 \mathrm{mg} \mathrm{kg}^{-1}$ and $22 \mathrm{mg} \mathrm{kg}^{-1}$, respectively. The study concludes that, on the basis of critical limits in soil and maize plant, $\mathrm{Zn}$ fertilization may be carried out for economic yield. 
cultivated. Zn influences quality and yields of crops (Alloway, 2003). It is a trace element needed in small but in critical concentrations. If the amount of zinc is not adequate in soils, plants will agonize from a physiological stress resulting from the dysfunction of several enzyme systems and other plant metabolic activities because it plays a vital role in several plant metabolic processes; it acts as a enzymes activator and also involved in the protein synthesis process and carbohydrate, lipid metabolism and nucleic acid (Marschner, 1986; Pahlsson, 1989). Nevertheless, like other all heavy metals (Doncheva, 1998) when $\mathrm{Zn}$ is stored in additional in plant tissues, it results in alterations in vital growth processes like chlorophyll biosynthesis and (Doncheva et al., 2001) and membrane integrity also (De Vos et al., 1991). According to (Chaoui et al., 1997) an additional quantity of $\mathrm{Zn}$ also has been stated to have an undesirable effect on mineral nutrition.

Maize belongs to Maideas tribe and grass family of Poaceae /Gramineae is categorized as the most sensitive cereal crop to $\mathrm{Zn}$ deficiency. However, $\mathrm{Zn}$ deficiency mainly occurs in maize crop plants as $\mathrm{Zn}$ plays so many important structural and functional roles in plant growth and development and a lack of $\mathrm{Zn}$ resulted to decreased seed formation (Bell and Dell, 2008). Zinc deficiency in human being also looks to be a critical nutritional and health hazards in the whole world. The severe challenge is being looked to enhance grain $\mathrm{Zn}$ concentration in agricultural crops to overawed widespread malnutrition problem especially in under developing and economically poor countries (Bouis and Welch, 2010). Therefore, with the increasing levels of $\mathrm{Zn}$ content in grain is results in providing more $\mathrm{Zn}$ to people, who belief directly or indirectly on pea-derived food. Zinc is also essential for the transportation of calcium throughout the maize plant.
Maize (Zea mays L.) is the third most important cereal crop of the world as well as India after wheat and rice. In India, maize is cultivated in 9.47 million hectares with an annual production of 28.72 million tonnes with the average productivity of $3,032 \mathrm{~kg} \mathrm{ha}^{-1}$ (Anonymous, 2018). Over 85\% of maize produced in the country grown throughout the year as three seasons as kharif, rabi and jayad season.

Maize is growing in Manipur in some pocket. Recently, the large scale cultivation of maize has picked up for grain crop as well as forage crop. Among the various agronomical practices for cultivation of maize crop, adequate and balanced fertilization plays an important role for increasing yield. Correcting the nutrient content in the soil and their ratio in plant parts during crop growth with yield and yield attributes is prerequisite to find out critical nutrients for optimum yield and quality of crop. Nutrient deficiency of plant can be corrected well in advance before heavy losses. However, a few research work has done on this aspect in NE Region, in general and Manipur, in particular and therefore, the present study was carried out to find out the response of maize to $\mathrm{Zn}$ fertilization in acidic soils and evaluate the critical limits of $\mathrm{Zn}$ in soil and plant.

\section{Materials and Methods}

Twenty soil samples $(0-15 \mathrm{~cm}$ depth) were collected from various cultivated paddy fields of Imphal East district in the month of MidDecember, 2018 in clean polythene bags for pot culture study. The soil samples were thoroughly dried in shade, ground with wooden pestle and mortar and passed through $2 \mathrm{~mm}$ sieve separately without any mixture of foreign material. The soil samples were stored in separate clean polythene bags with proper labels and used for further analyses of various physico-chemical properties of the soils. 


\begin{tabular}{|c|c|c|c|}
\hline SI No. & Place of Collection/Village & Latitude & Longitude \\
\hline 1. & Khurai & $\mathrm{N}-24^{\circ} 49^{\prime} 24.46$ & 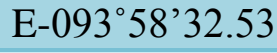 \\
\hline 2. & Khabeisoi-1 & $\mathrm{N}-24^{\circ} 50^{\prime} 29.08$ & E- $093^{\circ} 58^{\prime} 50.81$ \\
\hline 3. & Khabeisoi-2 & $\mathrm{N}-24^{\circ} 51^{\prime} 04.61$ & E-093⒌'3 31.61 \\
\hline 4. & Cingarel-1 & $\mathrm{N}-24^{\circ} 51^{\prime} 37.40$ & E- $090^{\circ} 00^{\prime} 00.00$ \\
\hline 5. & Sawombung-1 & $\mathrm{N}-24^{\circ} 52^{\prime} 23.22$ & E- $094^{\circ} 00^{\prime} 44.49$ \\
\hline 6. & Sawombung-2 & $\mathrm{N}-24^{\circ} 53^{\prime} 06.86$ & E-0940'’31.97 \\
\hline 7. & Keibikhullen-1 & $\mathrm{N}-24^{\circ} 54^{\prime} 37.15$ & E-094º2’19.73 \\
\hline 8. & Keibikhullen-2 & $\mathrm{N}-24^{\circ} 55^{\prime} 01.96$ & 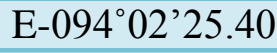 \\
\hline 9. & Lamboikhul-1 & $\mathrm{N}-24^{\circ} 55^{\prime} 58.31$ & E- $094^{\circ} 02^{\prime} 53.71$ \\
\hline 10. & Lamboikhul-2 & $\mathrm{N}-24^{\circ} 56^{\prime} 29.88$ & E- $094^{\circ} 02^{\prime} 39.06$ \\
\hline 11. & Chingarel-2 & $\mathrm{N}-24^{\circ} 51^{\prime} 33.25$ & E-093ํ5'58.41 \\
\hline 12. & Phaknung-1 & $\mathrm{N}-24^{\circ} 52^{\prime} 01.23$ & E- $094^{\circ} 00^{\prime} 44.08$ \\
\hline 13. & Phaknung-2 & $\mathrm{N}-24^{\circ} 51^{\prime} 27.44$ & E-094º0’08.06 \\
\hline 14. & Waiton & $\mathrm{N}-24^{\circ} 52^{\prime} 09.12$ & E-093ㄷํ'⒍92 \\
\hline 15. & Pangei & $\mathrm{N}-24^{\circ} 51^{\prime} 59.32$ & E-093도'32.99 \\
\hline 16. & Basihkhong & $\mathrm{N}-24^{\circ} 45^{\prime} 11.06$ & E-0935'신 11.45 \\
\hline 17. & Uchkeckon & $\mathrm{N}-24^{\circ} 46^{\prime} 14.04$ & 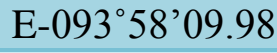 \\
\hline 18. & Yaralpat & $\mathrm{N}-24^{\circ} 46^{\prime} 30.31$ & E-093ㄷㅇ'11.16 \\
\hline 19. & Keikhu & $\mathrm{N}-24^{\circ} 47^{\prime} 11.03$ & E-093도'02.78 \\
\hline 20. & Kongba & $\mathrm{N}-24^{\circ} 45^{\prime} 45.87$ & E-0935ㄱ'06.54 \\
\hline
\end{tabular}

Mechanical analysis was carried out by hydrometer method (Bouyoucos, 1962). These samples were analysed for soil $\mathrm{pH}, \mathrm{EC}$ and CEC using standard procedures as described by Jackson, (1973) and Borah et al., (1987). Available $\mathrm{N}, \mathrm{P}_{2} \mathrm{O}_{5}$ and $\mathrm{K}_{2} \mathrm{O}$ were determined by Subbiah and Asija (1956), Bray and Kurtz No.1 method (1945) and Jackson (1973), respectively.

Organic carbon was determined by wet oxidation method (Walkley and Black, 1934). Available zinc of the soil was determined by using Atomic Adsorption Spectrophotometer (ASS) as described by Lindsay and Norvell (1978).

Three $\mathrm{kg}$ of soils were filled in pots and $\mathrm{Zn}$ were applied $0.0,2.5$ and $5.0 \mathrm{~kg} \mathrm{Zn} \mathrm{ha}{ }^{-1}$ through $\mathrm{ZnSO}_{4} \cdot 7 \mathrm{H}_{2} \mathrm{O}$. The treatments were replicated thrice in completely randomized design. A basal dose of N:P:K @ 100:50:40 $\mathrm{ha}^{-1}$ in the form of urea, SSP and MOP were applied in each pot. Hybrid maize variety PAC-740 was sown and thin to one plant in each pot after germination. The moisture level was maintained at field capacity in all the pots by watering with distilled water as and when needed.

The crop was harvested at 45 days of growing. The plant samples were washed to remove the dirt and then oven dried at $65^{\circ} \mathrm{C}$ for 48 hours and the dry matter yield was recorded. The plant samples were ground and powdered samples were analysed for $\mathrm{N}$ by microkjeldahl method, $\mathrm{P}, \mathrm{K}$ and $\mathrm{Zn}$ by diacid, $\mathrm{HNO}_{3}: \mathrm{HClO}_{4}$ digestion and using vanadomolybdophosphoric acid yellow colour method by spectrophotometry and plant potassium by flame photometry method (Jackson, 1973) and $\mathrm{Zn}$ by using Atomic Adsorption Spectrophotometer (ASS) as described by Lindsay and Norvell (1978). The 
critical limits of soil and plant were determined by technique of Cate and Nelson (1965). Bray's per cent yield and uptake of maize was calculated as:

Bray's per centyield $=\frac{\text { Yield withoutfertilizer }}{\text { Maximumyield in fertilizer treated pots }}$ x 100

Bray's per cent uptake $=\frac{\text { Uptake withoutfertilizer }}{\text { Maximum uptake infertilizer treated pots }}$ X 100

All data obtained from the present experiment were computed as per method described by Gomez and Gomez, (1984) to obtain the mean and standard deviation of zinc conc. in the different pools. In addition correlation analysis was done to obtain the relationship among zinc conc. in various pools and various soil properties. The significance of various effects was tested at 5\% level of probability.

\section{Results and Discussion}

The initial physico-chemical properties of the soils of Imphal East district of Manipur are presented in Table 1. All the soil samples were clay in textural class. The soils were acidic in nature which ranged from 5.01 to $6.08 \mathrm{pH}$ (mean 5.42), EC varied from 0.04 to $0.18 \mathrm{dSm}^{-1}$ at $25^{\circ} \mathrm{C}, \mathrm{CEC}$ ranged from 12.59 to $23.75\left[\mathrm{cmol}\left(\mathrm{p}^{+}\right) \mathrm{kg}^{-1}\right]$, and organic carbon content of the soils are high, it varied from 8.28 to $23.77 \mathrm{~g} \mathrm{kh}^{-1}$. The available $\mathrm{N}, \mathrm{P}_{2} \mathrm{O}_{5}$ and $\mathrm{K}_{2} \mathrm{O}$ content of the different soils samples collected from various paddy fields ranged from 214.12 to $407.09,21.21$ to 39.49 and 226.44 to $322.94 \mathrm{~kg} \mathrm{ha}^{-1}$, respectively.

\section{Dry matter yield}

The dry matter yield of hybrid maize PAC740 was affected with the fertilization of $\mathrm{Zn}$ regardless of the initial soil properties. Dry matter yield of control ranged from 2.80 to $4.82 \mathrm{~g} / \mathrm{pot}$ as compared with 2.95 to 5.00 $\mathrm{g} /$ pot in $2.5 \mathrm{~kg} \mathrm{ZnSO}_{4} \mathrm{ha}^{-1}$ and 3.18 to 5.28 $\mathrm{g} /$ pot in $5.00 \mathrm{~kg} \mathrm{ZnSO}_{4} \mathrm{ha}^{-1}$ (Table 2). The fertilization of $5.00 \mathrm{ZnSO}_{4} \mathrm{ha}^{-1}$ results in highest dry matter yield significantly. The increased dry matter yield due to $\mathrm{Zn}$ fertilization might be due to increase plant high and leave area of the plant. Application of zinc produced the higher straw yield of paddy was also reported by Mustafa et al., (2011). This result is in conformity with findings of Keram et al., (2012) in wheat and Singh et al., (1999) reported that the application of $5.0 \mathrm{mg} \mathrm{Zn} \mathrm{Kg}{ }^{-1}$ increased dry matter yield of rice significantly. Application of $6 \mathrm{~kg} \mathrm{Zn} \mathrm{ha}{ }^{-1}$ increased the green foliage and dry matter yield of maize was also reported by Singh and Singh (2017). Application of $\mathrm{Zn}$ and $\mathrm{Cu}$ had significant increased the dry matter production was reported by Eteng et al., (2014).

\section{Nitrogen, phosphorus, potassium and zinc uptake}

The nitrogen, phosphorus, potassium and zinc uptake by the maize plant increased with the increasing level of $\mathrm{Zn}$ fertilization (Table 2 and 3) which is significantly superior to the other treatments except phosphorus uptake. The uptake of these nutrients by the plant might be the combined effect of higher nutrient concentration in the plant and higher dry matter yield. Application of $\mathrm{Zn}$ fertilizer had increased the $\mathrm{N}$ concentration and $\mathrm{N}$ uptake by the plant (Potarzyeki and Grzebisz, 2009). N and Zn uptake had increased with the application of Zn (Sarwar et al., 2012). Increased $\mathrm{Zn}$ uptake by the maize plant with the application of $\mathrm{Zn}$ fertilizer was not only due to the plant biomass but also due to the $\mathrm{Zn}$ concentration in the plant (Grzebisz et al., 2008). $\mathrm{Zn}$ fertilization increased the $\mathrm{Zn}$ uptake by the maize was also reported by Eteng (2017). Application of $\mathrm{Zn}$ along with RDF had increased the uptake of N, P, K, S and $\mathrm{Zn}$ by the baby corn (Kumar et al., 2015). 
Table.1 Some physico-chemical properties of the

\begin{tabular}{|c|c|c|c|c|c|c|c|c|c|c|c|}
\hline $\begin{array}{l}\text { Soil } \\
\text { samples }\end{array}$ & $\begin{array}{l}\text { pH } \\
\text { (mol/lit.) }\end{array}$ & $\begin{array}{l}\mathrm{EC} \\
\left(\mathrm{dSm}^{-1}\right)\end{array}$ & $\begin{array}{l}\text { Org. C } \\
\left(\text { g kg }^{-1}\right)\end{array}$ & $\begin{array}{l}\text { Av. N } \\
\left(k^{-1} \text { ha }^{-1}\right)\end{array}$ & $\begin{array}{l}\text { Av. } P_{2} O_{5} \\
\left(k_{g} h^{-1}\right)\end{array}$ & $\begin{array}{l}\text { Av. } K_{2} \mathrm{O} \\
\left(\mathrm{kg} \mathrm{ha}^{-1}\right)\end{array}$ & $\begin{array}{l}\text { CEC } \\
{\left[\mathrm{cmol}\left(\mathrm{P}^{+}\right) \mathrm{kg}^{-1}\right]}\end{array}$ & $\begin{array}{l}\text { Sand } \\
(\%)\end{array}$ & $\begin{array}{l}\text { Silt } \\
(\%)\end{array}$ & $\begin{array}{l}\text { Clay } \\
(\%)\end{array}$ & $\begin{array}{l}\text { Textural } \\
\text { Class }\end{array}$ \\
\hline 1. & 5.25 & 0.04 & 17.09 & 253.64 & 37.66 & 257.85 & 15.41 & 17.63 & 32.15 & 50.22 & Clay \\
\hline 2. & 5.58 & 0.09 & 8.96 & 272.66 & 38.75 & 236.59 & 13.82 & 10.12 & 26.43 & 63.45 & Clay \\
\hline 3. & 6.05 & 0.10 & 22.10 & 274.88 & 28.46 & 291.06 & 16.14 & 9.80 & 23.28 & 66.92 & Clay \\
\hline 4. & 5.85 & 0.09 & 21.67 & 286.46 & 26.70 & 285.33 & 15.58 & 10.50 & 31.80 & 57.70 & Clay \\
\hline 5. & 5.90 & 0.07 & 16.32 & 301.62 & 37.38 & 270.19 & 12.59 & 16.39 & 36.03 & 47.58 & Clay \\
\hline 6. & 5.28 & 0.06 & 15.75 & 292.67 & 36.20 & 250.23 & 15.84 & 19.84 & 34.46 & 45.70 & Clay \\
\hline 7. & 5.69 & 0.13 & 8.28 & 221.45 & 39.49 & 226.44 & 18.72 & 10.15 & 30.50 & 59.35 & Clay \\
\hline 8. & 6.08 & 0.11 & 19.60 & 268.70 & 32.91 & 306.52 & 15.62 & 8.61 & 27.85 & 63.54 & Clay \\
\hline 9. & 5.02 & 0.06 & 15.68 & 214.12 & 31.88 & 242.09 & 17.44 & 23.94 & 32.56 & 43.50 & Clay \\
\hline 10. & 5.95 & 0.09 & 20.17 & 287.37 & 28.44 & 322.75 & 16.60 & 9.90 & 34.03 & 56.07 & Clay \\
\hline 11. & 5.01 & 0.08 & 20.07 & 402.69 & 23.15 & 265.56 & 14.40 & 11.40 & 31.50 & 57.10 & Clay \\
\hline 12. & 5.05 & 0.16 & 19.63 & 407.09 & 22.49 & 296.08 & 15.07 & 11.86 & 27.64 & 60.50 & Clay \\
\hline 13. & 5.03 & 0.18 & 23.77 & 341.45 & 21.21 & 322.94 & 23.75 & 10.00 & 23.54 & 66.46 & Clay \\
\hline 14. & 5.35 & 0.05 & 19.10 & 348.48 & 25.41 & 253.71 & 16.00 & 12.50 & 27.63 & 59.87 & Clay \\
\hline 15. & 5.60 & 0.15 & 18.11 & 425.83 & 22.02 & 253.78 & 16.12 & 12.20 & 38.95 & 48.85 & Clay \\
\hline 16. & 5.40 & 0.10 & 17.66 & 249.76 & 37.20 & 282.70 & 16.28 & 10.34 & 36.10 & 53.56 & Clay \\
\hline 17. & 5.07 & 0.06 & 17.51 & 238.85 & 32.49 & 270.56 & 18.65 & 18.49 & 29.50 & 52.01 & Clay \\
\hline 18. & 5.03 & 0.11 & 15.70 & 289.21 & 27.17 & 267.76 & 16.48 & 25.35 & 27.34 & 47.31 & Clay \\
\hline 19. & 5.02 & 0.13 & 16.96 & 247.42 & 36.27 & 236.38 & 14.01 & 17.78 & 22.73 & 59.49 & Clay \\
\hline 20. & 5.10 & 0.15 & 20.12 & 370.40 & 21.84 & 291.73 & 18.75 & 10.65 & 31.50 & 57.85 & Clay \\
\hline Mean & 5.42 & 0.10 & 17.71 & 299.74 & 30.36 & 271.51 & 16.36 & 13.87 & 30.28 & 55.85 & \\
\hline
\end{tabular}


Table.2 Effects of Zn application on dry matter yield, zinc concentration and its uptake by Maize crop

\begin{tabular}{|c|c|c|c|c|c|c|c|c|c|c|c|c|}
\hline \multirow[t]{2}{*}{$\begin{array}{c}\text { Soil } \\
\text { samples }\end{array}$} & \multirow{2}{*}{$\begin{array}{c}\text { DTPA } \\
\text { extractable- } \\
\text { Zn }\end{array}$} & \multicolumn{3}{|c|}{$\begin{array}{c}\text { Dry matter yield (g/pot) } \mathbf{Z n} \\
\text { level }\left(\mathrm{kg} \mathrm{ha}^{-1}\right)\end{array}$} & \multirow[t]{2}{*}{$\begin{array}{l}\text { Bray's } \\
\% \text { yield }\end{array}$} & \multicolumn{3}{|c|}{$\begin{array}{c}\text { Zn conc. in plants (ppm) } \\
Z \mathbf{Z n} \text { level }\left(\mathrm{kg} \mathrm{ha}^{-1}\right)\end{array}$} & \multicolumn{3}{|c|}{$\begin{array}{c}\text { Zn uptake by plant } \\
\text { (mg/pot) Zn level }\left(\mathrm{kg} \mathrm{ha}^{-1}\right)\end{array}$} & \multirow{2}{*}{$\begin{array}{l}\text { Bray's } \\
\% \text { Zn } \\
\text { uptake }\end{array}$} \\
\hline & & 0 & 2.5 & 5.0 & & 0 & 2.5 & 5.0 & 0 & 2.5 & 5.0 & \\
\hline 1. & 0.94 & 3.95 & 4.12 & 4.28 & 92.29 & 24.00 & 23.93 & 25.67 & 0.09 & 0.10 & 0.11 & 86.31 \\
\hline 2. & 0.75 & 3.30 & 3.44 & 3.62 & 91.16 & 21.60 & 21.00 & 23.33 & 0.07 & 0.07 & 0.08 & 84.03 \\
\hline 3. & 0.92 & 3.65 & 3.80 & 3.96 & 92.17 & 23.00 & 24.00 & 25.55 & 0.08 & 0.09 & 0.10 & 83.00 \\
\hline 4. & 0.88 & 3.80 & 3.90 & 4.22 & 90.05 & 22.00 & 23.00 & 24.82 & 0.08 & 0.09 & 0.10 & 79.89 \\
\hline 5. & 0.66 & 2.80 & 2.95 & 3.18 & 88.05 & 18.63 & 20.00 & 22.58 & 0.05 & 0.06 & 0.07 & 72.65 \\
\hline 6. & 0.87 & 3.68 & 3.85 & 4.05 & 90.86 & 22.00 & 22.00 & 24.13 & 0.08 & 0.08 & 0.10 & 82.84 \\
\hline 7. & 0.82 & 3.60 & 3.72 & 3.98 & 90.45 & 22.00 & 22.00 & 24.13 & 0.08 & 0.08 & 0.10 & 82.55 \\
\hline 8. & 0.72 & 3.00 & 3.24 & 3.38 & 88.76 & 18.97 & 21.00 & 23.35 & 0.06 & 0.07 & 0.08 & 72.10 \\
\hline 9. & 0.98 & 4.05 & 4.16 & 4.24 & 95.52 & 24.83 & 24.83 & 26.46 & 0.10 & 0.10 & 0.11 & 89.65 \\
\hline 10. & 1.15 & 4.20 & 4.44 & 4.61 & 91.11 & 26.00 & 28.00 & 28.76 & 0.11 & 0.12 & 0.13 & 82.32 \\
\hline 11. & 1.26 & 4.30 & 4.50 & 4.68 & 91.88 & 28.00 & 28.00 & 29.57 & 0.12 & 0.13 & 0.14 & 87.03 \\
\hline 12. & 1.24 & 4.72 & 4.94 & 5.22 & 90.42 & 30.00 & 32.00 & 34.22 & 0.14 & 0.16 & 0.18 & 79.27 \\
\hline 13. & 1.70 & 4.82 & 5.00 & 5.28 & 91.29 & 33.63 & 35.13 & 35.80 & 0.16 & 0.18 & 0.19 & 85.67 \\
\hline 14. & 1.35 & 4.40 & 4.60 & 4.78 & 92.05 & 28.00 & 28.97 & 30.34 & 0.12 & 0.13 & 0.15 & 84.90 \\
\hline 15. & 1.40 & 4.62 & 4.80 & 4.96 & 93.15 & 28.97 & 31.00 & 32.67 & 0.13 & 0.15 & 0.16 & 82.58 \\
\hline 16. & 0.98 & 3.98 & 4.20 & 4.41 & 90.25 & 24.00 & 24.00 & 26.46 & 0.10 & 0.10 & 0.12 & 81.82 \\
\hline 17. & 0.99 & 4.12 & 4.34 & 4.46 & 92.38 & 24.83 & 26.00 & 27.26 & 0.10 & 0.11 & 0.12 & 84.15 \\
\hline 18. & 1.23 & 4.30 & 4.50 & 4.69 & 91.68 & 28.00 & 28.97 & 29.56 & 0.12 & 0.13 & 0.14 & 86.84 \\
\hline 19. & 0.74 & 3.05 & 3.20 & 3.38 & 90.24 & 21.57 & 20.00 & 23.35 & 0.07 & 0.06 & 0.08 & 83.62 \\
\hline 20. & 1.37 & 4.46 & 4.70 & 4.88 & 91.39 & 30.00 & 31.00 & 31.12 & 0.13 & 0.15 & 0.15 & 88.12 \\
\hline Mean & 1.05 & 3.94 & 4.12 & 4.31 & 91.26 & 25.00 & 25.74 & 27.46 & 0.10 & 0.11 & 0.12 & 82.97 \\
\hline \multicolumn{5}{|c|}{$\begin{array}{l}\text { CD at } 5 \% \text { for } \mathrm{Zn}=0.04 \\
\mathrm{CD} \text { at } 5 \% \text { for soil }=0.10 \\
\mathrm{CD} \text { at } 5 \% \text { for } \mathrm{Zn} \times \text { soil }=\mathbf{0 . 1 7}\end{array}$} & \multicolumn{4}{|c|}{$\begin{array}{l}\text { CD at } 5 \% \text { for } \mathrm{Zn}=\mathbf{0 . 1 9 2} \\
\mathrm{CD} \text { at } 5 \% \text { for } \mathrm{soil}=\mathbf{0 . 4 9 6} \\
\mathrm{CD} \text { at } 5 \% \text { for } \mathrm{Zn} \times \mathrm{xoil}=\mathbf{0 . 8 6 0}\end{array}$} & \multicolumn{4}{|c|}{$\begin{array}{l}C D \text { at } 5 \% \text { for } \mathrm{Zn}=0.19 \\
C D \text { at } 5 \% \text { for soil }=0.49 \\
C D \text { at } 5 \% \text { for } \mathrm{Zn} \times \text { soil }=0.85\end{array}$} \\
\hline
\end{tabular}


Table.3 Effect of zinc application on nitrogen, phosphorous and potassium uptake by maize crop

\begin{tabular}{|c|c|c|c|c|c|c|c|c|c|c|c|c|}
\hline \multirow[t]{2}{*}{$\begin{array}{c}\text { Soil } \\
\text { samples }\end{array}$} & \multicolumn{3}{|c|}{$\begin{array}{c}\text { N Uptake by plants } \\
\text { (mg/pot) } \\
\text { Zn level (kg ha-1) }\end{array}$} & \multirow[b]{2}{*}{ Mean } & \multicolumn{3}{|c|}{$\begin{array}{c}\text { P Uptake by plants } \\
\text { (mg/pot) } \\
\text { Zn level (kg ha-1 })\end{array}$} & \multirow[b]{2}{*}{ Mean } & \multicolumn{3}{|c|}{$\begin{array}{c}\text { K Uptake by plants } \\
\text { (mg/pot) } \\
\left.\text { Zn level (kg ha }{ }^{-1}\right)\end{array}$} & \multirow[b]{2}{*}{ Mean } \\
\hline & 0 & 2.5 & 5.0 & & 0 & 2.5 & 5.0 & & 0 & 2.5 & 5.0 & \\
\hline 1. & 125.66 & 132.72 & 139.58 & 132.66 & 9.48 & 9.48 & 9.85 & 9.60 & 90.09 & 96.45 & 101.91 & 96.15 \\
\hline 2. & 88.92 & 93.72 & 101.16 & 94.60 & 7.59 & 7.57 & 7.61 & 7.59 & 73.95 & 79.85 & 84.74 & 79.51 \\
\hline 3. & 82.52 & 130.12 & 136.28 & 116.31 & 8.76 & 8.75 & 8.72 & 8.74 & 84.72 & 89.79 & 95.87 & 90.13 \\
\hline 4. & 109.46 & 118.61 & 130.88 & 119.65 & 9.51 & 9.36 & 9.29 & 9.39 & 85.99 & 90.52 & 99.64 & 92.05 \\
\hline 5. & 72.27 & 76.64 & 83.35 & 77.42 & 6.16 & 6.19 & 6.68 & 6.34 & 35.86 & 40.09 & 47.08 & 41.01 \\
\hline 6. & 105.17 & 115.55 & 125.61 & 115.44 & 8.47 & 8.47 & 8.92 & 8.62 & 83.20 & 88.59 & 96.43 & 89.41 \\
\hline 7. & 102.28 & 106.41 & 118.42 & 109.04 & 8.64 & 8.70 & 9.15 & 8.83 & 73.47 & 80.09 & 88.32 & 80.62 \\
\hline 8. & 79.64 & 87.62 & 92.09 & 86.45 & 7.05 & 7.13 & 7.44 & 7.21 & 45.62 & 53.91 & 56.92 & 52.15 \\
\hline 9. & 132.90 & 139.84 & 145.92 & 139.55 & 9.72 & 9.57 & 9.76 & 9.68 & 94.81 & 100.72 & 105.20 & 100.24 \\
\hline 10. & 151.26 & 163.46 & 171.82 & 162.18 & 10.51 & 10.66 & 11.07 & 10.75 & 102.39 & 110.16 & 117.67 & 110.07 \\
\hline 11. & 161.89 & 172.87 & 180.72 & 171.83 & 10.76 & 10.81 & 10.77 & 10.78 & 105.82 & 114.34 & 120.79 & 113.65 \\
\hline 12. & 191.24 & 201.64 & 217.25 & 203.38 & 13.22 & 13.36 & 14.12 & 13.57 & 124.82 & 140.36 & 152.32 & 139.16 \\
\hline 13. & 200.25 & 216.92 & 234.53 & 217.24 & 13.98 & 14.01 & 14.28 & 14.09 & 130.45 & 142.39 & 155.65 & 142.83 \\
\hline 14. & 173.44 & 183.00 & 194.29 & 183.57 & 11.44 & 11.50 & 10.53 & 11.16 & 112.25 & 120.56 & 128.41 & 120.41 \\
\hline 15. & 182.57 & 190.28 & 203.45 & 192.10 & 12.49 & 12.49 & 12.41 & 12.46 & 117.40 & 123.97 & 133.15 & 124.84 \\
\hline 16. & 136.06 & 146.22 & 157.95 & 146.74 & 9.55 & 9.24 & 9.71 & 9.50 & 93.89 & 102.52 & 110.30 & 102.24 \\
\hline 17. & 141.79 & 153.58 & 161.52 & 152.30 & 10.31 & 10.40 & 10.26 & 10.32 & 97.28 & 104.99 & 110.66 & 104.31 \\
\hline 18. & 166.91 & 176.47 & 185.80 & 176.39 & 10.32 & 11.16 & 10.32 & 10.60 & 106.68 & 115.25 & 124.02 & 115.32 \\
\hline 19. & 81.27 & 86.86 & 94.12 & 87.42 & 7.02 & 7.04 & 7.10 & 7.05 & 59.50 & 65.63 & 71.69 & 65.61 \\
\hline 20. & 176.25 & 187.91 & 197.73 & 187.30 & 11.60 & 11.75 & 12.20 & 11.85 & 114.22 & 124.28 & 135.88 & 124.80 \\
\hline Mean & 133.09 & 144.02 & 153.62 & 143.58 & 9.83 & 9.88 & 10.01 & 9.91 & 91.62 & 99.22 & 106.83 & 99.23 \\
\hline \multicolumn{5}{|c|}{$\begin{array}{l}\text { CD at } 5 \% \text { for } \mathrm{Zn}=\mathbf{2 . 7 3} \\
\mathrm{CD} \text { at } 5 \% \text { for soil }=\mathbf{7 . 0 5} \\
\mathrm{CD} \text { at } 5 \% \text { for } \mathrm{Zn} \times \text { soil }=\mathbf{1 2 . 2 2}\end{array}$} & \multicolumn{4}{|c|}{$\begin{array}{l}C D \text { at } 5 \% \text { for } \mathrm{Zn}=0.19 \\
C D \text { at } 5 \% \text { for soil }=0.50 \\
C D \text { at } 5 \% \text { for } \mathrm{Zn} \times \text { soil }=0.87\end{array}$} & \multicolumn{4}{|c|}{$\begin{array}{l}C D \text { at } 5 \% \text { for } \mathrm{Zn}=1.87 \\
\mathrm{CD} \text { at } 5 \% \text { for soil }=4.83 \\
\mathrm{CD} \text { at } 5 \% \text { for } \mathrm{Zn} \times \text { soil }=8.37\end{array}$} \\
\hline
\end{tabular}


Fig.1 Scatter diagram showing relationship between Bray's per cent yield of Maize crop plant and DTPA extractable zinc in soil

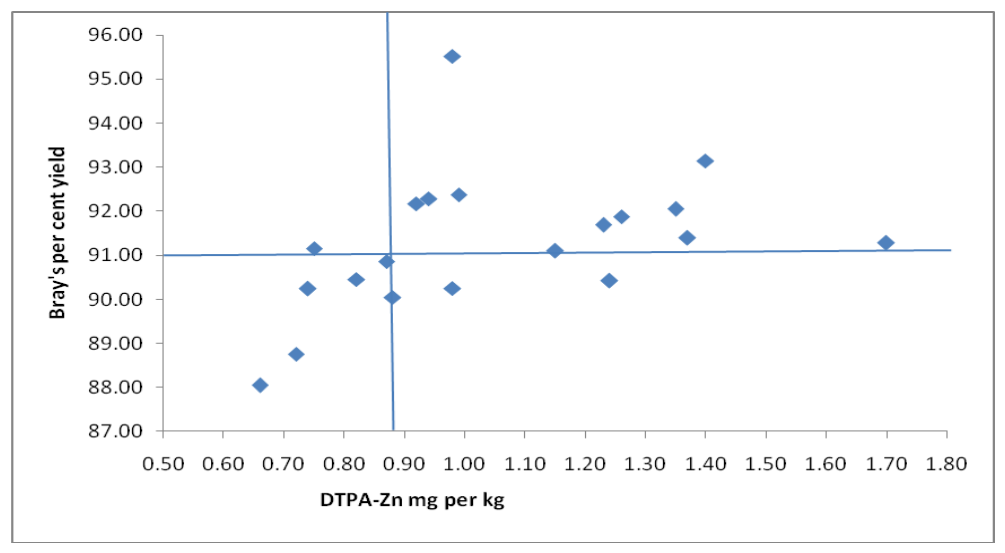

Fig.2 Scatter diagram showing relationship between Bray's per cent yield and tissue zinc concentration in Maize crop plant

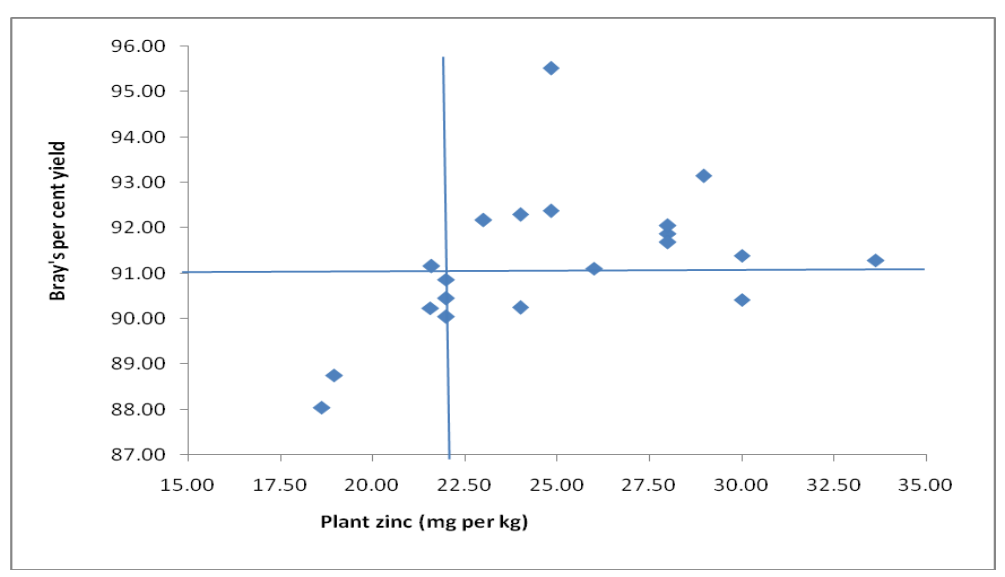

\section{Critical limit of $\mathrm{Zn}$ in soil and plant}

Base on the graphical procedure of Cate and Nelson (1965), the critical limit of $\mathrm{Zn}$ in soils and maize plant (hybrid PAC-740) were 0.88 $\mathrm{mg} \mathrm{kg}$ (Fig. 1) and $22 \mathrm{mg} \mathrm{kg}^{-1}$ (Fig. 2), respectively. A soil was to be considered as non-responsive to $\mathrm{Zn}$ fertilization where Bray's per cent dry matter was more than 91. All the soil testing below $0.88 \mathrm{mg} \mathrm{kg}^{-1}$ by DTPA-extractable $\mathrm{Zn}$ may be responded to $\mathrm{Zn}$ fertilization for growing maize plant. A value of $22 \mathrm{mg} \mathrm{kg}^{-1}$ could distinguish the $\mathrm{Zn}$ deficient plants from those of sufficient ones, partitioning the two dimensional percentage yield versus $\mathrm{Zn}$ content in 45 days old plant scattered into two groups. Similarly, Kumari et al., (2013) reported that the critical limit of available $\mathrm{Zn}$ was $0.75 \mathrm{mg} \mathrm{kg}^{-1}$ and the critical concentration of $\mathrm{Zn}$ in 45 days old maize plant tissue was $22.5 \mathrm{mg} \mathrm{kg}^{-1}$. Thus, the present study lays emphasis on $\mathrm{Zn}$ fertilization on maize plant on the basis of critical values in the soils and plant.

\section{References}

Alloway, B.J. 2004. Zinc in soils and crop nutrition. Brussels, Belgium: International Zinc Association.

Anonymous, 2018. Directorate of Economics and statistics, Department of Agriculture, 
Cooperation and Farmer Welfare, Government of India.

Bell, R.W. and Dell, B. (2008). Micronutrient for Sustainable Food, Feed, Fibre and Bioenergy Production. International Fertilizer Industry Association, Paris, France.

Bouis, H.E. and Welch, R.M. (2010). Biofortification sustainable agricultural strategy for reducing micronutrient malnutrition in the Global South. Crop Sciences. 50(1): 20-32.

Bouyoucous, G.J. (1962). Hydrometer method improved for making analysis of soils. Agronomy Journal. 54: 464-465.

Borah, D.K., Bordoloi, P.K., Karmakar, R.M., Baruah, N.G. and Das, M. (1987). Practical Manual for Fundamental of Soil Science (Part-III). Jorhat (Assam).

Bray, R.H. and Kurtz, L.T. (1945). Determination of total, organic and available forms of phosphorous in soils. Soil Science. 59: 39-45.

Cate, R.B. and Nelson, L.A. (1965). Graphical procedure for critical limits of nutrients. Proceeding of the Soil Science Society of America. 89: 658.

Chaoui, A., Mazhoudi, S., Ghorbal, M.H. and Elferjani, E. (1997). Cadmium and zinc induction of lipid peroxidation and effects on antioxidant enzyme activities in bean (Phaseolus vulgaris L.). Plant Science. 127: 139-147.

De Vos, C.H.R., Schat, H., De Waal, M.A.M., Voorja, R. and Ernst, W.H.O. (1991). Increased resistance to copper-induced damage of root cell plasmalemma in copper tolerant Silenecucubalus. Plant Physiology. 82: 523-528.

Doncheva, S. (1998). Copper-induced alterations in structure and proliferation of root meristem cells. Journal of Plant Physiology. 153: 482-487.

Doncheva, S., Stoyanova, Z. and Velikova, V. (2001).The influence of succinate on zinc toxicity of pea plant. Journal of Plant
Nutrition. 24: 789-806.

Eteng, E.U., Asawalam, D.O. and Ano, A.O. 2014. Effect of $\mathrm{Cu}$ and $\mathrm{Zn}$ on maize (Zea mays, L.) yield and nutrient uptake in coastal plain sand derived soils of Southestern Nigeria. Open Journal of Soil Science. 4: 235-245.

Eteng, E.U. 2017. Response of Zn uptake, grain and other yield components of five maize hybrids as influenced by $\mathrm{Zn}$ fertilization methods in a marginal coastal plain sand soil. International Journal of Research Studies in Science, Engineering and Technology. 4(12): 3746.

Gomez, K.A. and Gomez, A.A. (1984).Statistical procedures for agricultural research. John Wiley and sons.Inc. London, UK ( $\left.2^{\text {nd }} e d n\right)$.

Grzebisz, W., Wronska, M., Diatta, J.B. and Dullin, P. 2008. Effect of zinc foliar application at an early stage of maize growth on patterns of nutrients and dry matter accumulation by the canopy. Part I. zinc uptake patterns and its redistribution among maize organs. Journal of Elementology. 13(1): 17-28.

Jackson, M.L. (1973). Soil Chemical Analysis, Prentice Hall of India Pvt. Ltd. New Delhi.

Keram, K.S., Sharma, B.L. and Sawarkar, S.D. (2012). Impact of zinc application on yield, quality, nutrients uptake and soil fertility in a medium deep black soil (Vertisol). International Journal of Science, Environment and Technology. 1(5): 563-571.

Kumar, R., Kumawat, N., Kumar, S., Singh, A.K. and Bohra, J.S. 2015. Effect of NPKS and Zn fertilization on growth, yield and quality of baby corn-A Review. International Journal of Microbiology and Applied Sciences. 6(3): 1392-1428.

Kumar, M., Jha, A.K., Hazarika, S., Verma, B.C., Choudhury, B.U., Ramesh, T. and Devi, M.H. (2016). Micronutrients (B, 
$\mathrm{Zn}$, Mo) for improving crop production on acidic soils of Northeast India. National Academy of Science Letters. 39(2): 85-89.

Kumari, M., Yadav, K. and Nisha, K. (2013). Critical limits of zinc in soil and plants for Maize in Diaraland soils of Bihar. Environment and Ecology. 31(2C): 11071110.

Lindsay, W.L. and Norvell, W.A. (1978).Development of DTPA soil test for zinc, manganese and copper. Soil Science Society of America Journal. 42: 421-428.

Marschner, H. (1986). Mineral nutrition of higher plants. Academic Press, New York.

Mustafa, G., Ehsanulla, Akbar, N., Qaisrani, S.A., Iqbal, A. Khan, H.Z, Jabran, K, Chattha, A.A., Trethowan, R., Chattha, T. and Atta, B.M. 2011. Effect of zinc application on growth and yield of rice (Oryza sativa L.). International Journal for Agro Veterinary and Medical Sciences. 5(6): 530-535.

Nene, Y.L. (1966). Symptoms, cause and control of khaira disease of paddy. Bulletin of Indian Phytophathological Society No. 3: 97-101.

Pahlsson, A.M.B. (1989). Toxicity of heavy metals $(\mathrm{Zn}, \mathrm{Cu}, \mathrm{Cd}, \mathrm{Pb})$ to vascular plants. Water, Air and Soil Pollution. 47: 287-319.

Potarzycki, J. and Grzebisz, W. (2009). Effect of zinc foliar application on grain yield of maize and its yielding components. Plant, Soil and Environment. 55(12):
519-527.

Sarwar, M., Jilani, G., Rafique, E., Akhtar, M.E. and Chaudhry, A.N. 2012. Impact og integrated nutrient management of yield and nutrient uptake by maize under rain-fed conditions. Pakistan Journal of Nutrition. 11(1): 27-33.

Singh, M.V. (2000). Micronutrients in Indian soils and plants. Progress report of AICRP of micro and secondary-nutrients and pollutant elements in soils and plants. 29: $1-122$.

Singh, M.V. (2001b). Evaluation of micronutrients status in different agroecological zones of India. Fertilizers News. 46 (2): 25-42.

Singh, A.K., Nongkynrih, P. and Khan, S.K. (1999). Critical limit of zinc deficiency for predicting response of rice soils of Meghalaya. Journal of the Indian Society of Soil Science. 47: 567-569.

Singh, S. and Singh, V. 2017. Productivity, quality and nutrients uptake of maize (Zea mays) as affected by sources and levels of zinc. Annals of Plant and Soil research. 19(1): 95-99.

Subbiah, B.V. and Asija, G.L. (1956).A rapid procedure for estimation of available $\mathrm{N}$ in soils. Current Sciences. 25: 259-260.

Walkley, A. and Black, I.A. (1934).An examination of the Degtjareff method determining soil organic matter, and a proposed modification of the chromic acid titration method. Soil Science. 34: 29-38.

\section{How to cite this article:}

Pawan Kumar, Herojit Singh Athokpam, R. K. Kumarjit Singh, Konthoujam Nandini Devi and Naorem Okendro Singh. 2020. Estimation of Critical Limits of Zinc in Soil and Plant for Predicting Response of Maize (Zea mays L.) to Zinc and Nutrient Uptake in Acid Soils, Manipur. Int.J.Curr.Microbiol.App.Sci. 9(10): 2052-2061.

doi: https://doi.org/10.20546/ijcmas.2020.910.251 